\title{
Scenarios from the Eta Model on quality and hydrological quantity in the Atlantic Forest, Southern Brazil
}

\author{
Cenários do modelo Eta na qualidade e quantidade hidrológica na Mata Atlântica, Sul do Brasil
}

\author{
Adilson Pinheiro ${ }^{1}$ (D), Vander Kaufmann ${ }^{1}$ (D), Gustavo Antonio Piazza ${ }^{1}$ (D) and Claudia Guimarães Camargo Campo ${ }^{2}$ (D) \\ ${ }^{1}$ Fundação Universidade Regional de Blumenau, Blumenau, SC, Brasil \\ ${ }^{2}$ Universidade do Estado de Santa Catarina, Lages, SC, Brasil
}

E-mails: pinheiro@furb.br (AP), vanderkaufmann@gmail.com (VK), gustavoapiazza@gmail.com (GAP), claudia.campos@udesc.br (CGCC)

Received: November 30, 2018 - Revised: May 16, 2019 - Accepted: June 10, 2019

\begin{abstract}
This work evaluated the response of two scenarios (4.5 and 8.5) of the Eta Model on the quality (sediment - TSS, nitrate - NO ${ }_{3}^{-}$and phosphate - $\mathrm{PO}_{4}^{3-}$ ) and quantity (flow - Q) of the Concordia Catchment in the Atlantic forest biome. The importance of the work lies in the comparison of both scenarios until 2099, using current agricultural practices (2016). The SWAT model normally used for hydrological purposes has been applied to evaluate water quality from the monitoring programme database (2010-2014). Q showed a non-accentuated, upward trend. Modifications in Q were transmitted to TSS and $\mathrm{PO}_{4}^{3-}$. There was no significant difference between the tested scenarios.
\end{abstract}

Keywords: Temporal variations; Hysteresis; Soil management.

\section{RESUMO}

Este trabalho avaliou a resposta de dois cenários (4.5 e 8.5) do modelo Eta sobre a qualidade (sedimento - TSS, nitrato - NO ${ }_{3}$ e fosfato - $\mathrm{PO}_{4}$ ) e quantidade (vazão - Q) na bacia hidrográfica do Ribeirão Concórdia, no bioma Mata Atlântica. A importância do trabalho está na verificação dos cenários até o ano de 2099, tendo em vista as práticas agrícolas atuais (2016). Foi utilizado o modelo SWAT, geralmente aplicado para processos hidrológicos, no sentido de avaliar a qualidade da água, por meio do monitoramento mensal na bacia hidrográfica (2010-2014). Q apresentou uma tendência de aumento não acentuado. Modificações em Q foram transmitidas para TSS e $\mathrm{PO}_{4}$. Não houve diferença significativa entre os cenários testados.

Palavras-chave: Variações temporais; Histerese; Manejo do solo.

\section{INTRODUCTION}

Climate change effects are felt in water resources and, consequently, in ecological, social, and economic systems (DIBIKE; COULIBALY, 2005; BRAUMAN et al., 2007; VÖRÖSMARTY et al., 2010; MEAURIO et al., 2017). These effects can be observed on local, regional, and global scales. The Intergovernmental Panel on Climate Change (IPCC) has already warned about the risks related to increased water use. According to the IPCC's Fifth Assessment Report (AR5), the global mean surface temperature increased by $0.85^{\circ} \mathrm{C}$ from 1880 to 2012 , and the beginning of the 21 st century was the hottest ever recorded (IPCC, 2013). High temperatures also elevate evapotranspiration rates, which are directly linked to water systems (PAPARRIZOS et al., 2016; URRUTIA; VUILLE, 2009).

To understand how these systems will respond to climate change, climate models are used, such as the general circulation model (GCM), which estimates scenarios of atmospheric and oceanic circulation. These models are evaluate the impacts of climate change on meteorological systems, providing different results (outputs), which feed hydrological models (GOSLING et al., 2011). With a GCM, it is possible to estimate the impact of climate change and make future projections at the catchment level (SELLAMI et al., 2016; ZHANG et al., 2016; OUYANG et al., 2015; TAN et al., 2014). To generalise the scenarios, the IPCC presented, in the AR5, the Coupled Model Intercomparison Project Phase 5 (CMIP5), which established four climate scenarios, called Representative Concentration 
Pathways (RCPs) (MEINSHAUSEN et al., 2011; TAYLOR et al., 2012). These RCPs consider different scales of radioactive forcing $\left(\mathrm{Wm}^{-2}\right)$ and the base value established for the pre-industrial period (VAN VUUREN et al., 2011).

The Soil and Water Assessment Tool (SWAT) is a physical-based model applied to hydrological simulation in catchments. Generally, the SWAT model is used to investigate changes in hydrological conditions over different environments and practices (GASSMAN et al., 2007; KRYSANOVA; WHITE, 2015). In SWAT, complex natural phenomena can be simulated, using simplified equations (BLAINSKI et al., 2017). Studies, such as Tan et al. (2017), Yesuf et al. (2016) and Fukunaga et al. (2015), have already demonstrated the model's reliability for simulating flow in tropical regions, but not for quality, which still needs improvement.

Recently, the impact of climate change on hydrological processes has gained attention, resulting in a considerable number of new studies in various regions and even in some Brazilian catchments (MACHADO et al., 2003; LELIS et al., 2012; SILVA et al., 2011; BLAINSKI et al., 2014; VIOLA et al., 2015; ALVARENGA et al., 2018; TAFFARELLO et al., 2018; COSTA et al., 2019). Impact assessments of climate change are valuable information for managing water resources and developing management plans. Computational advances through geographical information systems (GIS) also facilitate the representation of the changes (BLAINSKI et al., 2017). To achieve a satisfactory representation, however, a high amount of information is needed, preferably via field monitoring (NEITSCH et al., 2011; ARNOLD et al., 2012a), which may be the limiting factor for using this tool (e.g., BEVEN, 2001; BRESSIANI et al., 2015).

Catchment management in developing countries is still incipient. For example, the Itajaí-Açú River Catchment, is made up of $15,000 \mathrm{~km}^{2}$ in the Atlantic Forest Biome and includes 49 municipalities. The catchment committee is active but cannot handle the number of complex local activities, such as urban centres (i.e., public supply and industrial activities) and agricultural areas (i.e., irrigation and livestock). The unplanned use of water resources and the effects of climate change, however, has generated a warning about the availability of water resources, both in quantity and quality. The site is naturally vulnerable and historically suffers from intense precipitation rates and floods, which are becoming more frequent (PIAZZA et al., 2016). One way to manage the impacts of these events is to study catchment responses while determining possible future scenarios. Even with increasing technological advances, modelling water quality in Brazilian catchments is still incipient (BLAINSKI et al., 2017) due to the lack of databases with quality data. This fact places the Concordia Catchment in a privileged situation in terms of catchment management, due to its having a large database of monitoring data.

This study aimed to evaluate the effects of two climate change scenarios (RCP 4.5 and 8.5) using SWAT to estimate future scenarios of water quantity (flow - Q) and quality (sediment - TSS, nitrate - $\mathrm{NO}_{3}$, and phosphate - $\mathrm{PO}_{4}{ }^{3-}$ ) in the Concordia Catchment. The study was divided into two steps: (1) evaluation of SWAT model for simulating flow; and (2) the response of TSS, $\mathrm{NO}_{3}{ }^{-}$and $\mathrm{PO}_{4}^{3-}$ concentrations until 2099.

\section{MATERIAL AND METHODS}

\section{Study site}

The study site was the Concordia Stream Catchment, which consists of an agricultural catchment of $30 \mathrm{~km}^{2}$. The Concordia Stream is a tributary of the Lontras River, which is a tributary of the Itajaí River, the largest catchment on the Atlantic side of the state of Santa Catarina (Figure 1).

Besides its importance as a source of water, the Itajai River Catchment also has great economic importance. The Itajai River rises in the mountain regions and sheds in the west-east direction to the Atlantic Ocean. The Concordia Catchment is a representative, sub-catchment of the Itajaí River Catchment, as it presents the same type of land use; with native forests in the upper areas, and agriculture and some planted forests in the less mountainous areas. The main crops are maize, beans, tobacco, soy, cassava, oats, and some fruit trees. In the bottomlands, it is also possible to find wetlands used for rice cultivation.

The elevation in the region ranges from $330 \mathrm{~m}$ in the low areas to $900 \mathrm{~m}$ in the upper areas. The precipitation rates vary annually from 1,800 $\mathrm{mm}$ to 2,200 $\mathrm{mm}$ (PIAZZA et al., 2016). Almost $60 \%$ of the total annual rainfall occurs in the wet season (summer), from December to March. However, the occurrence of rainfall is well distributed throughout the year. Although summer is the wet season, the average river flow is low then, compared to winter, since summer is also responsible for the highest evapotranspiration rates (PIAZZA et al., 2018). The catchment climate is determined by the Serra Geral, which separates the coastal plain from an interior plateau, and it is characterised as humid subtropical (Köppen's Cfa), with an annual average temperature of $20^{\circ} \mathrm{C}$. Land use consists of: $45 \%$ native forest, $20 \%$ pasture, $14 \%$ planted forests (Pinus spp. And eucalyptus ssp.), 12\% agriculture, $5 \%$ forest in the initial stage of regeneration, $2 \%$ exposed soil, $1 \%$ water, and $1 \%$ urban.

\section{Hydrometeorological data}

The meteorological monitoring was performed by a meteorological station located at an altitude of $534 \mathrm{~m}$. Data were collected hourly and stored in a datalogger. The station follows World Meteorological Organization (WMO) standards, and, in total, it contains: a luviography, a thermo hygrometer, a leaf wetness sensor, a pyranometer, a barometer and an anemometer. The data consists of five years of monitoring (April 2010 to December 2014). To complement the period, nine years of data (from 2002 to 2010 ) from a nearby (25 km) station (Ituporanga) were used.

Daily flow data were obtained from the fluviometric monitoring section near the outlet. The place had three rulers to measure water level and was monitored by a level sensor. To validate the data, the site was accompanied with flow measurements. Flow data comprised six (06) hydrological years. Rainfall data, also over six (06) hydrological years (2008 to 2014), were obtained from the sub-hourly data of nine (09) pluviographs randomly inserted in the catchment. Rainfall data between 2002 and 2008 were also adopted from the Ituporanga station. 


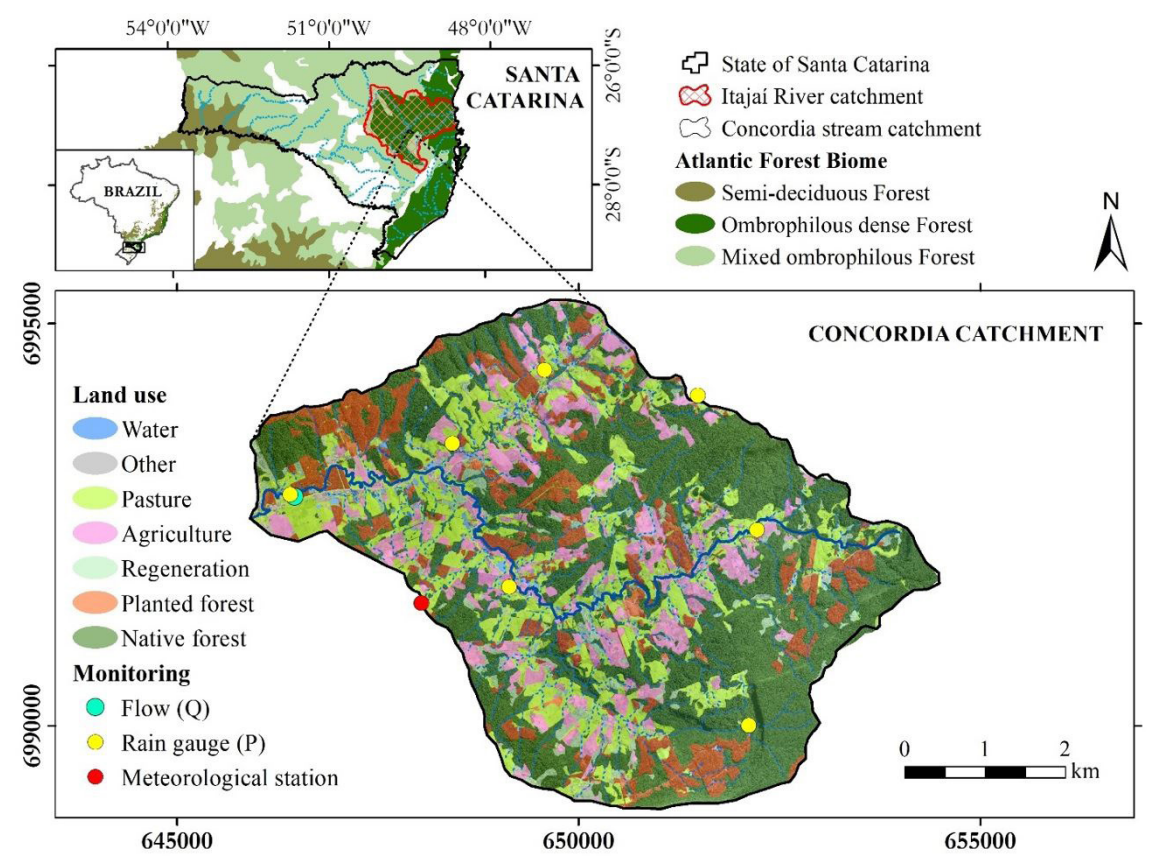

Figure 1. Location and land use of the Concordia Catchment in the Itajaí River Catchment, Santa Catarina, Southern Brazil.

\section{Sediment and quality data}

Three variables were chosen for quality modelling: total suspended sediment (TSS), nitrate $\left(\mathrm{NO}_{3}^{-}\right)$and phosphate $\left(\mathrm{PO}_{4}^{3-}\right)$, which are associated with local agricultural. They were also chosen due to the availability of data from the Concordia Catchment monitoring programme. Sediment was monitored with a turbidimeter (resolution 0 to 3000 NTU), and nutrient concentrations were determined through biweekly samples, analysed by an ion exchange chromatograph.

\section{Geospatial data}

Cartographic data included digital elevation model (DEM), water drainage, soil type and land use. All information presented high spatial resolution $(1 \mathrm{~m} \times 1 \mathrm{~m})$. The DEM in the raster format was obtained in the digital address SIGSC of the Secretaria de Desenvolvimento Sustentável (Secretariat for Sustainable Development - SDS) of Santa Catarina. The DEM was used to extract the flow direction and flow accumulation, create the drainage network, delimit the hydrographic basin and calculate the parameters. Land use data were generated by high-resolution image classification, also from SDS. The land use map was reclassified for SWAT requirements. Soil type data were obtained from the Brazilian Soil Map (EMBRAPA, 2004) in a 1:250,000 scale. All data processing was performed in ArcSWAT and its version within the geographic information software, ArcGIS 10.3.

\section{The SWAT model}

The SWAT model is a physical- and hydrological-based model used to evaluate the impact of climatic variability on long-term, hydrological processes in river catchments (STRAUCH et al., 2012).
It is a continuous time model and has been used to simulate long periods (ARNOLD et al., 2012a). SWAT is applied to simulate quantitative and qualitative hydrological processes. SWAT has, as principle, the catchment surface and its sub-catchments, as delineated by DEM. The smallest sub-catchment delineated by SWAT is called the Hydrological Response Unit (HRU), which is used to calculate the water balance. Each HRU has climatic, edaphic, topographic, vegetative and soil components, allowing simulation of flow, sediment and nutrients at different levels (BLAINSKI et al. 2017). The accumulated HRUs provide the cumulative result, up to the catchment outlet. The hydrological cycle in SWAT is based on the equation of the hydrological balance (ARNOLD et al., 2012a), as well as the evapotranspiration (ETo) estimated by the Penman-Monteith method (ALLEN et al., 1989). In this research, the peak flow was estimated by the modified rational formula. The surface runoff was calculated by the Soil Conservation Service Curve Number (SCS-CN) (NEITSCH et al., 2011), and the erosion was calculated with the Modified Universal Equation of Soil Loss (MUSLE) (WILLIAMS, 1975).

\section{Eta RCP scenarios}

To understand the behaviour of changes in atmospheric composition, two climate change scenarios (RCPs) were defined (IPCC, 2013). The RCP base provided data on emission projections and concentrations. 4.5 and 8.5 RCPs, which respectively represent medium and high emission scenarios, were used to design future scenarios. RCP 4.5 was a stabilisation scenario, in which the total radioactive force was projected as having been stabilised before the year 2100 using technologies and strategies to reduce greenhouse gases, while RCP 8.5 was a scenario of increased greenhouse gas concentrations. Projection data for climatic changes were obtained from an historical, daily series of the regional climatic Eta Model-HadGEM2-ES, with a resolution of $20 \mathrm{~km}$, used 
to detail the simulations of the HadGEM2-ES model, in the proposed scenarios (BRASIL, 2016).

To correct the systematic errors of GCMs and RCMs, bias removal techniques were applied, such as quantile-quantile mapping (BÁRDOSSY; PEGRAM, 2011), the delta change approach and the direct approach (LENDERINK et al., 2007), among others. Comparisons between different methods of bias removal can be found in Themeßl et al. (2011) and Teutschbein and Seibert (2012).

\section{Model application and data analysis}

In hydrological modelling, it is indispensable to calibrate the model parameters using the observed fluviometric series (BLAINSKI et al., 2017). Data from 2002 to 2008 (from the Ituporanga station) were considered for heating the model for flow and precipitation. The 2009 to 2012 period was used for calibration. Calibration and sensitivity analysis were performed automatically using the internal SWAT-CUP software, with the sequential uncertainty adjustment algorithm (or Sequential Uncertainty Fitting-SUFI-2). The algorithm relies on user-defined simulations to map uncertainties in parameters and capture measured data with a prediction uncertainty of 95\% (95 PPU) (ABBASPOUR et al., 2007). Most of the selected parameters were uncertainties of the parameters themselves and are difficult to measure in the field because of the lack of more available information (BLAINSKI et al., 2017). The range of these values were defined based on similar research and adjusted to represent natural processes (SANTHI et al.,
2001; ANDRADE, 2011; ARNOLD et al., 2012b; BRIGHENTI; BONUMÁ; CHAFFE, 2016).

To evaluate the performance of the SWAT, we used: the Nash-Sutcliffe efficiency coefficient (NSE) (NASH; SUTCLIFFE, 1970) and the coefficient of determination $\left(\mathrm{R}^{2}\right)$ (GUPTA et al., 1999).

The model was run on a daily and monthly basis, and, considering the last reference year (2016), the agricultural calendar followed the same behaviour for the simulated period. Thus, agricultural management remained the same throughout the data horizon (both in winter and summer), only comparing the climatic conditions of the 4.5 and 8.5 scenarios. Eight future horizons were considered: 2015-2024, 2025-2034, 2035-2044, 2045-2054, 2055-2064, 2065-2074, 2065-2074 and 2075-2084. The water quality was described by concentrations of TSS, $\mathrm{NO}_{3}^{-}$and $\mathrm{PO}_{4}^{3-}$. Seasonal and annual averages and tendencies, as well as frequency curves, were calculated by linear regression and the coefficient of determination $\left(\mathrm{R}^{2}\right)$, as described in Piazza et al. (2016).

\section{RESULTS AND DISCUSSION}

\section{Calibration}

Figure 2 shows the observed and simulated hygrograms for the calibration period (2010 to 2014). The Nash coefficients for daily and monthly data were 0.755 and 0.90 , respectively. The SWAT model overestimated peak flows in extreme precipitation events.

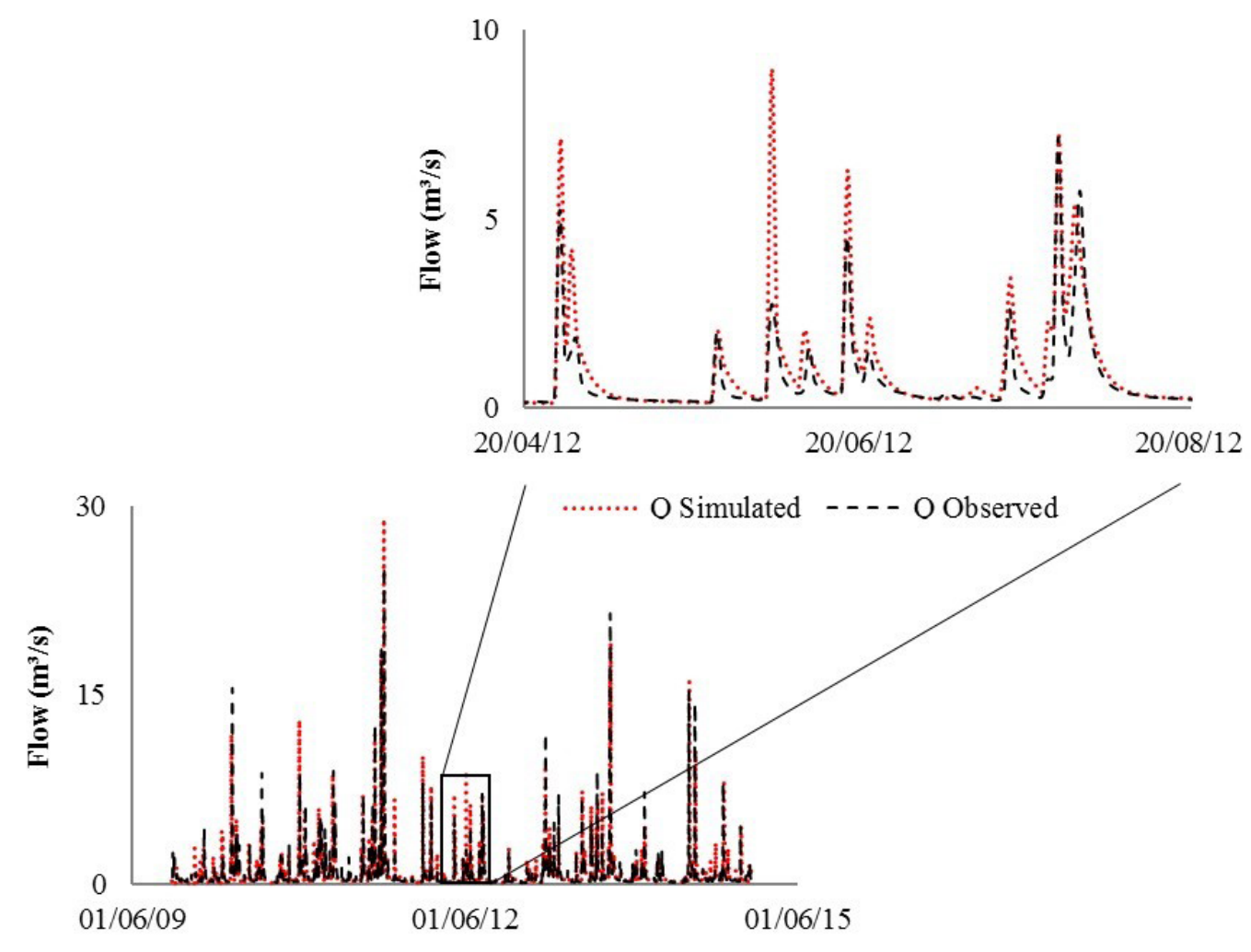

Time (days)

Figure 2. Observed and simulated hygrograms via SWAT in the Concordia Catchment, Southern Brazil. 
A possible cause for this was the reduced amount of measured flow for high quotas, used in constructing the curves.

Figure 3 shows the observed and simulated chronicle for $\mathrm{NO}_{3}^{-}$and $\mathrm{PO}_{4}^{3-}$ during the calibration process.

The Nash coefficient for daily suspended sediment was low (0.11), as were those for nitrate $(0.13)$ and phosphate $(0.27)$ concentrations. The monitoring frequency of suspended sediment and nutrients was biweekly and did not consider baseflow or storm conditions. Local sediment transport processes and quality in streams are complex in this region, with correlations between concentrations of chemical species and variations in meso-scale indices, such as the El-Nino-South Oscillation (ENOS) (PIAZZA et al., 2018). The low Nash coefficient indicates precaution concerning the model's results for suspended sediments and chemical species used for characterisation purposes. Moriasi et al. (2007) also found low performances for simulation with water quality models when compared with hydrological modelling. However, trends in sediment and nutrient concentrations were adequately simulated by SWAT.

\section{Simulation}

There was no statistical difference between the averages of the 4.5 and 8.5 scenarios (Table 1). The simulated, annual average flow showed a positive trend, indicating an increase in water volume in the fluviometric section over the years, as well as the maximum simulated flow rate (Figure 4), which refers to

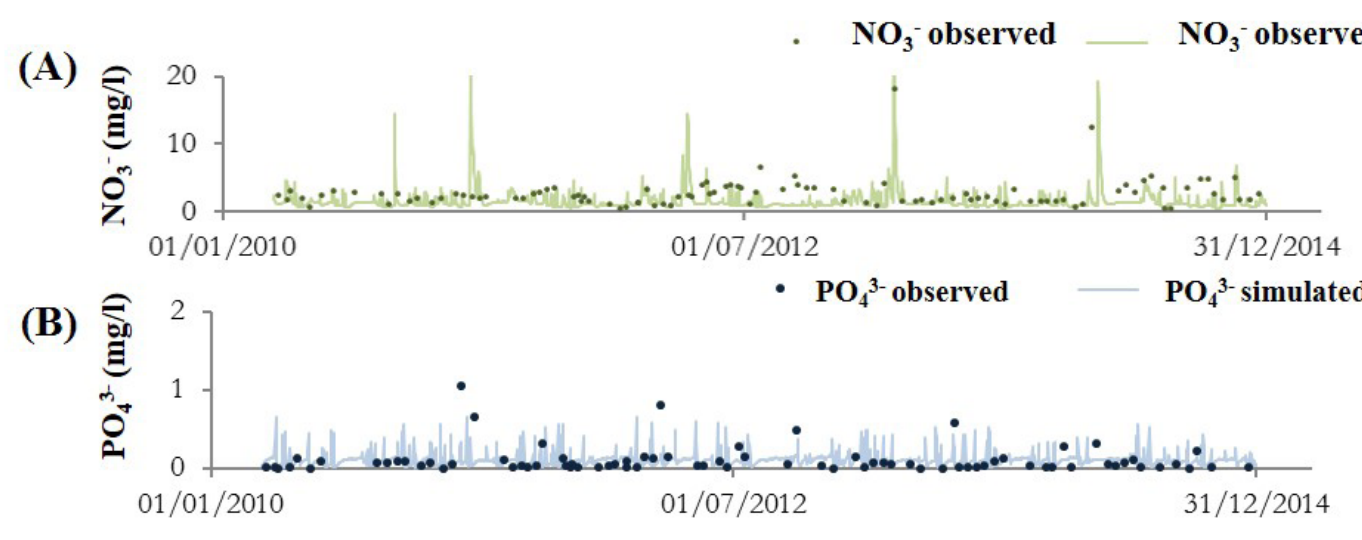

Time (days)

Figure 3. Observed and simulated chronicle for (A) $\mathrm{NO}_{3}^{-}$and (B) $\mathrm{PO}_{4}^{3-}$ in the Concordia Catchment, Southern Brazil.

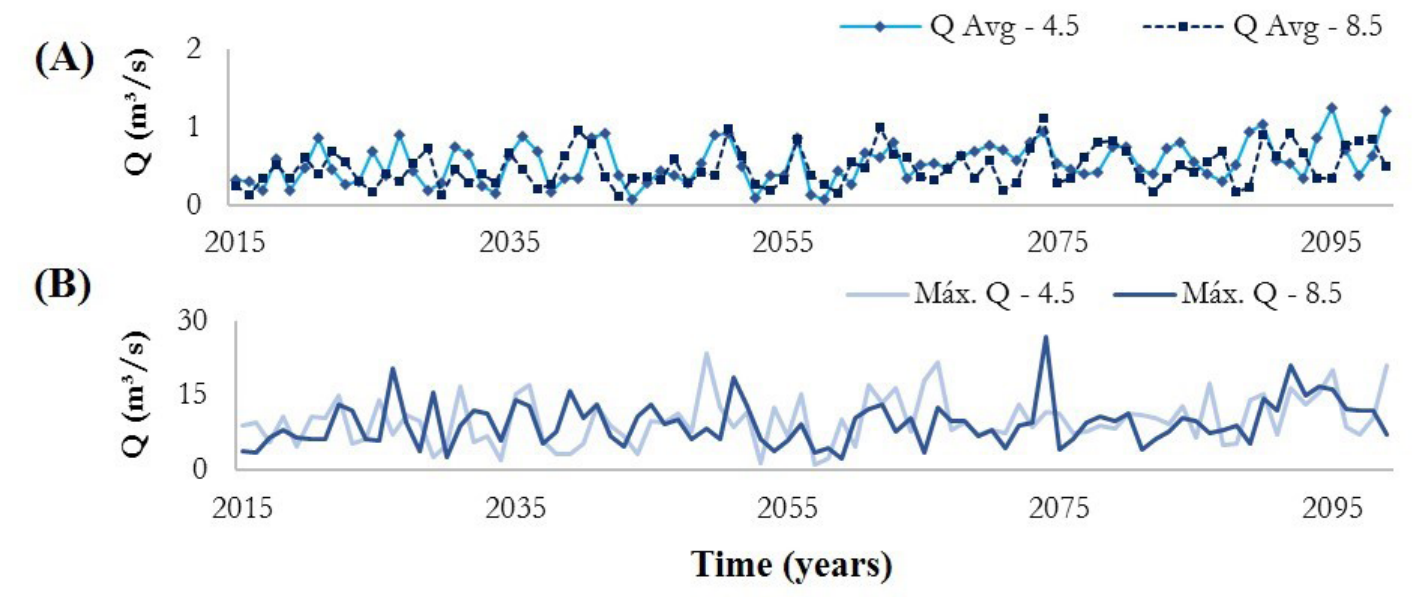

Figure 4. Time series of (A) average flow (Q Avg), (B) maximum flow (max. Q) from 2015 to 2099, Concordia Catchment, Southern Brazil.

Table 1. Summary of 4.5 and 8.5 scenarios from 2015 to 2099, Concordia catchment, Southern Brazil.

\begin{tabular}{|c|c|c|c|c|c|c|c|c|}
\hline & \multicolumn{2}{|c|}{$\mathrm{Q}\left(\mathrm{m}^{3} / \mathrm{s}\right)$} & \multicolumn{2}{|c|}{ TSS $\left(\mathrm{mg} \mathrm{L}^{-1}\right)$} & \multicolumn{2}{|c|}{$\mathrm{NO}_{3}^{-}\left(\mathrm{mg} \mathrm{L}^{-1}\right)$} & \multicolumn{2}{|c|}{$\mathrm{PO}_{4}^{3-}\left(\mathrm{mg} \mathrm{L}^{-1}\right)$} \\
\hline & 4.5 & 8.5 & 4.5 & 8.5 & 4.5 & 8.5 & 4.5 & 8.5 \\
\hline M. & 0.54 & 0.48 & 42.55 & 40.92 & 1.54 & 1.51 & 0.13 & 0.13 \\
\hline Med & 0.24 & 0.23 & 36.40 & 35.27 & 0.82 & 0.79 & 0.12 & 0.12 \\
\hline Max & 23.33 & 26.64 & 184.90 & 183.40 & 183.00 & 167.90 & 0.73 & 0.71 \\
\hline SD & 1.08 & 0.97 & 25.60 & 24.89 & 3.72 & 3.48 & 0.08 & 0.08 \\
\hline
\end{tabular}

Legend: $\mathrm{M}-$ mean, Med - median, Max - maximum, $\mathrm{SD}-$ standard-deviation, $\mathrm{Q}=$ flow, $\mathrm{TSS}=$ total suspended sediment, $\mathrm{NO}_{3}{ }^{-}=$nitrate, e $\mathrm{PO}_{4}{ }^{3-}=$ phosphate. 
extreme precipitation/flow. The trends were low due to the high variability of data related to the subsequent years, with a $0.3 \%$ increase per year for the 4.5 scenario and $0.2 \%$ increase per year for the 8.5 scenario. For maximum flow rate (or extreme events), results were more expressive, with a $4.9 \%$ increase per year for the 4.5 scenario and $3.6 \%$ increase per year for the 8.5 scenario. In the 8.5 scenario, the average flow rate over the years was lower than in the 4.5 scenario. This is associated with the warming conditions imposed by the 8.5 scenario, with a higher average temperature, which heightened evapotranspiration rates.

The TSS presented similar behaviour to flow (Q) (Figure 5A), with positive correlation. The seasonal pattern (Figure 5B) indicated lower concentrations in autumn (April to May), with peaks in Spring (mainly in October). The linear regression, estimated by the potential equation (Figure $5 \mathrm{C}$ ), presented a coefficient of determination of 0.93 for the 8.5 scenario and 0.86 for the 4.5 scenario. According to Blainski et al. (2017), conventional management in the region's agricultural catchments is the main source of sediments due unpaved roads and loss of the superficial layer of soil.

The interannual $\mathrm{NO}_{3}$ - concentration presented behaviour independent from Q and TSS (Figure 6A). The seasonal pattern (Figure 6B) for both scenarios (4.5 and 8.5) demonstrated higher concentrations in March and lower concentrations in May. March is the beginning of the agricultural calendar, when farmers prepare their lands for crops, revolving and applying synthetic and/or organic fertilisers. The coefficients of determination (Figure 6C) were low -0.02 for the 8.5 scenario and 0.08 for the 4.5 scenario.
The interannual variations of $\mathrm{PO}_{4}^{3-}$ presented similar behaviour to flow (Figure 7A). The seasonal pattern (Figure 7B) was inverse to flow for both scenarios (4.5 and 8.5), indicating dilution. The negative correlation was confirmed by the linear regression (Figure 7C). Coefficients of determination were 0.93 for the 8.5 scenario and 0.86 for the 4.5 scenario. Nitrate $\left(\mathrm{NO}_{3}{ }^{-}\right)$ and phosphate $\left(\mathrm{PO}_{4}{ }^{3}\right)$ showed no correlation, indicating different sources.

Figure 8 presents the $\mathrm{Q}$ hysteresis results for TSS, $\mathrm{NO}_{3}{ }^{-}$and $\mathrm{PO}_{4}^{3-}$. Q was the most sensitive parameter. TSS and $\mathrm{PO}_{4}^{3-}$ (less explicit) presented loop-type hysteresis, indicating correlation with $\mathrm{Q}$. The generated loop for Q x TSS presented a counter-clockwise direction, which characterised an increasing regime. The $\mathrm{Q} \times \mathrm{PO}_{4}^{3-}$ relationship presented a clockwise direction, indicating dilution. $\mathrm{NO}_{3}$ - presented no loop pattern due to the peak of concentration being in March and associated with the agricultural calendar. The hysteresis of $\mathrm{NO}_{3}^{-} \times \mathrm{PO}_{4}^{3-}$ also presented counter-clockwise behaviour.

The frequency analysis (Figure 9) corroborated the results, as $98 \%$ of the time $\left(\mathrm{F}_{98}\right) \mathrm{Q}$ ranged from $0.01255 \mathrm{~m}^{3} / \mathrm{s}$ to $0.01243 \mathrm{~m}^{3} / \mathrm{s}$ for the 4.5 and 8.5 scenarios, respectively. For TSS, $\mathrm{F}_{98}$ ranged from $8.729 \mathrm{mg} \mathrm{L}^{-1}$ for the 4.5 scenario to $9.221 \mathrm{mg} \mathrm{L}^{-1}$ for the 8.5 scenario. For $\mathrm{NO}_{3}^{-}, \mathrm{F}_{98}$ ranged from $0.391 \mathrm{mg} \mathrm{L}^{-1}$ to $0.3886 \mathrm{mg} \mathrm{L}^{-1}$ for the 4.5 and 8.5 scenarios, respectively. For $\mathrm{PO}_{4}^{3-}$ the $\mathrm{F}_{98}$ ranged from $0.0267 \mathrm{mg} \mathrm{L}^{-1}$ for the 4.5 scenario to $0.0268 \mathrm{mg} \mathrm{L}^{-1}$ for the 8.5 scenario.

The analyses of the eight decades (2015-2024, 2025-2034, 2035-2044, 2045-2054, 2055-2064, 2065-2074, 2065-2074 and 2075-2084) for Q, TSS, $\mathrm{NO}_{3}^{-}$and $\mathrm{PO}_{4}^{3-}$ (Figure 10) indicated stability

(A)

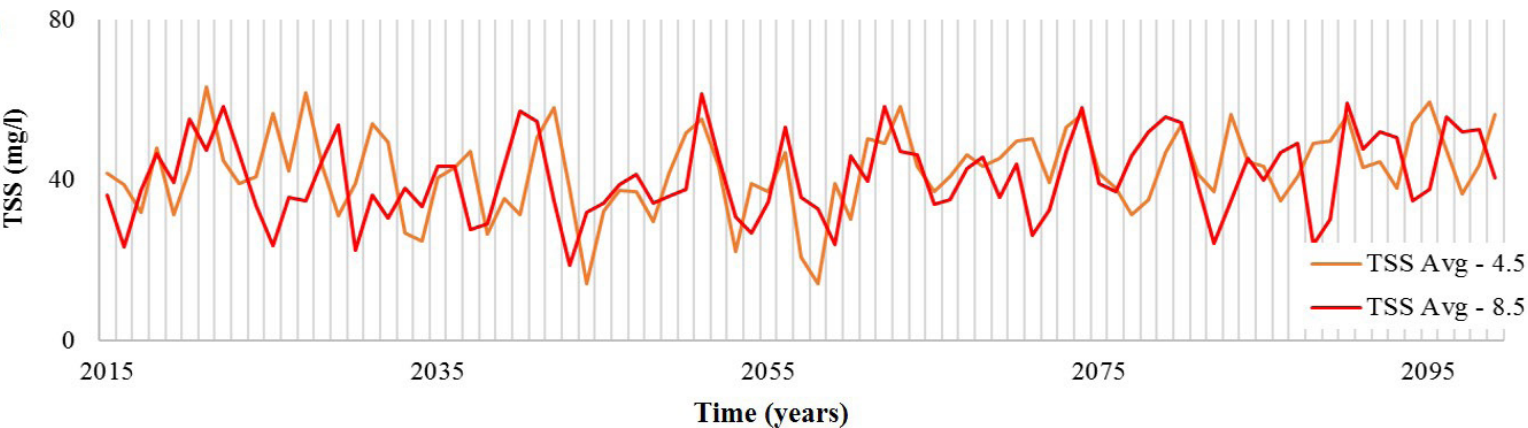

(B)

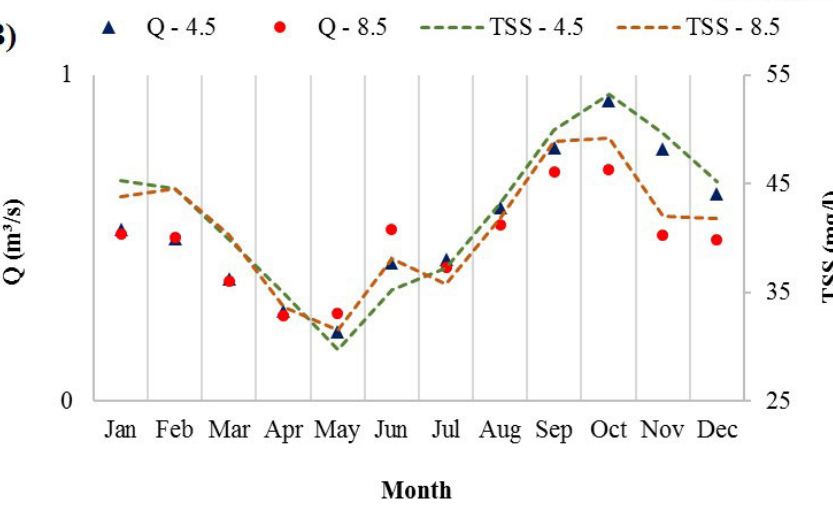

80 $\mathrm{y}=59.325 \mathrm{x}^{0.4716}$
$\mathrm{R}^{2}=0.9312$
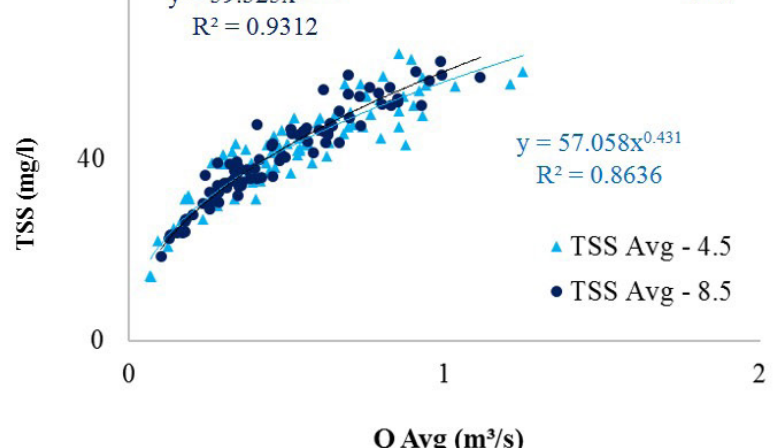

Q Avg $\left(\mathbf{m}^{3} / \mathbf{s}\right)$

Figure 5. (A) Interannual variation of TSS; (B) seasonal pattern of TSS and (C) linear regression of TSS and Q Avg, for 2015 to 2099, Concordia Catchment, Southern Brazil. 


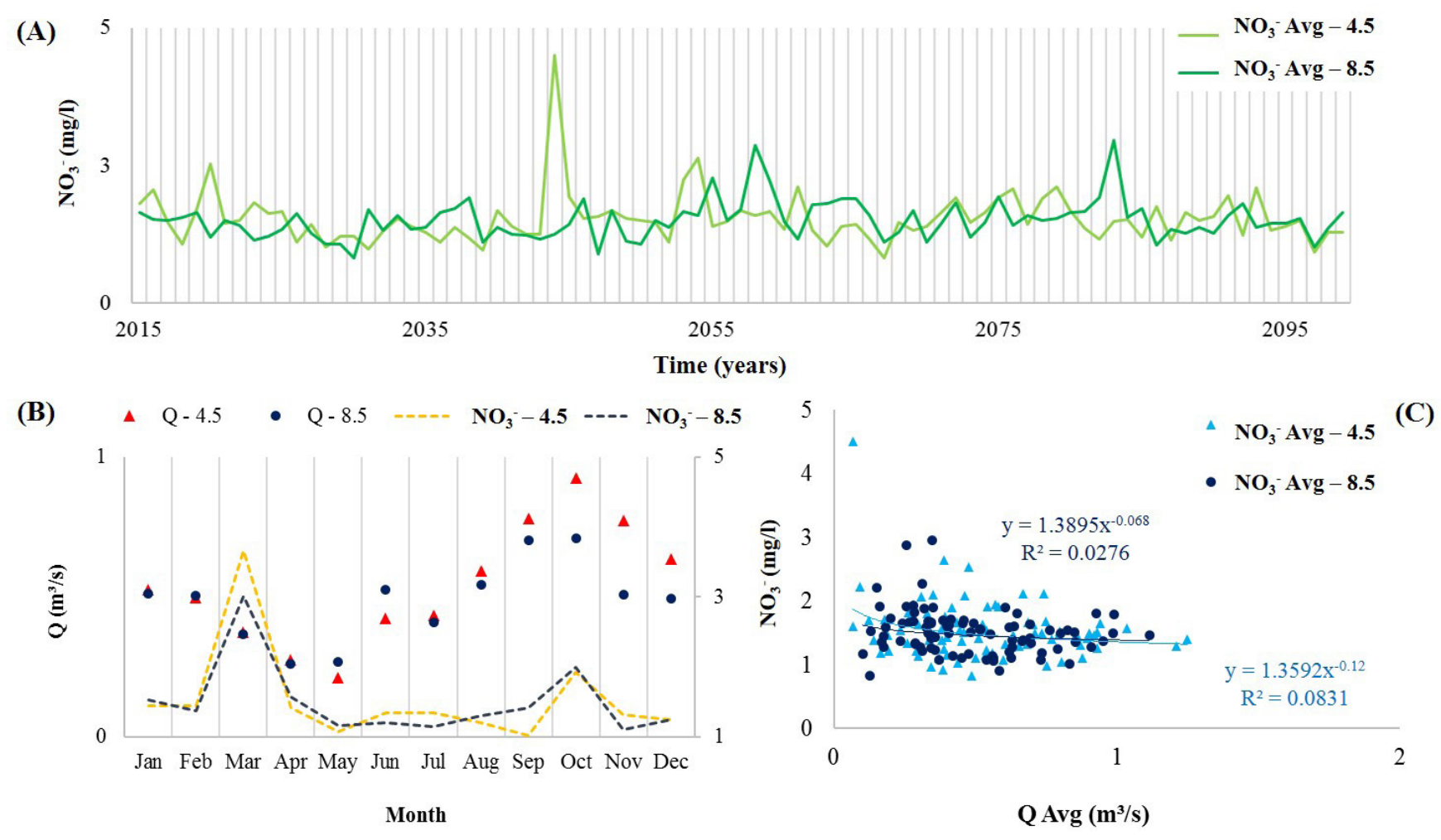

Figure 6. (A) Interannual variation of $\mathrm{NO}_{3}^{-}$, (B) seasonal pattern of $\mathrm{NO}_{3}^{-}$and (C) linear regression of $\mathrm{NO}_{3}^{-}$and $\mathrm{Q}^{-} \mathrm{Avg}$, for 2015 to 2099, Concordia Catchment, Southern Brazil.

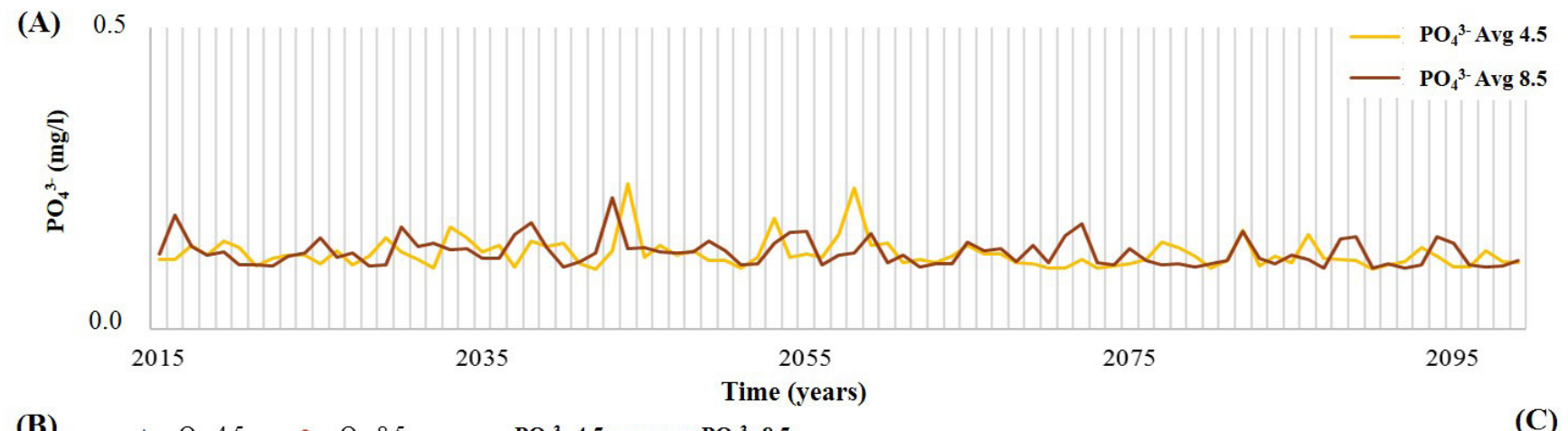

(B)

$\triangle \mathrm{Q}-4.5 \quad \mathrm{Q}-8.5---\mathrm{PO}_{4}{ }^{3-} 4.5---\mathrm{PO}_{4}{ }^{3-} \mathbf{8 . 5}$

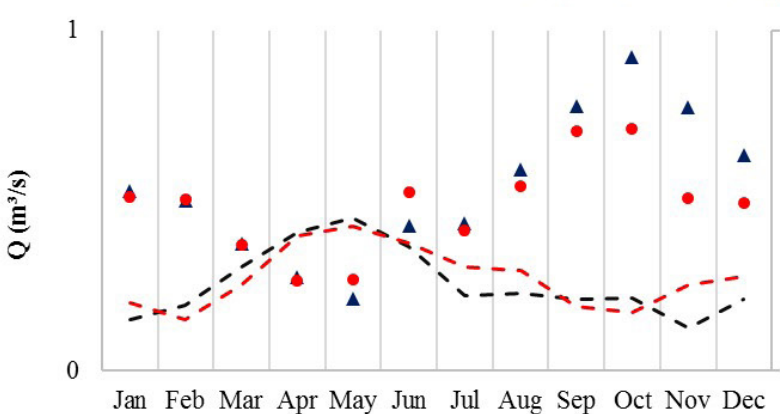

Month

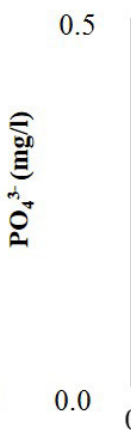

$\mathrm{y}=0.0996 \mathrm{x}^{-0.27}$

$\mathrm{R}^{2}=0.7637$

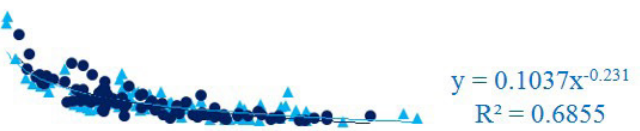

$\mathrm{R}^{2}=0.6855$

0.1

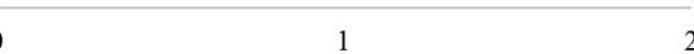

Q Avg $\left(\mathrm{m}^{3} / \mathrm{s}\right)$

Figure 7. (A) Interannual variation of $\mathrm{PO}_{4}^{3-}$, (B) seasonal pattern of $\mathrm{PO}_{4}^{3-}$ and (C) linear regression of $\mathrm{PO}_{4}^{3-}$ and $\mathrm{Q}$ Avg, for the period of 2015 to 2099, Concordia Catchment, Southern Brazil. 

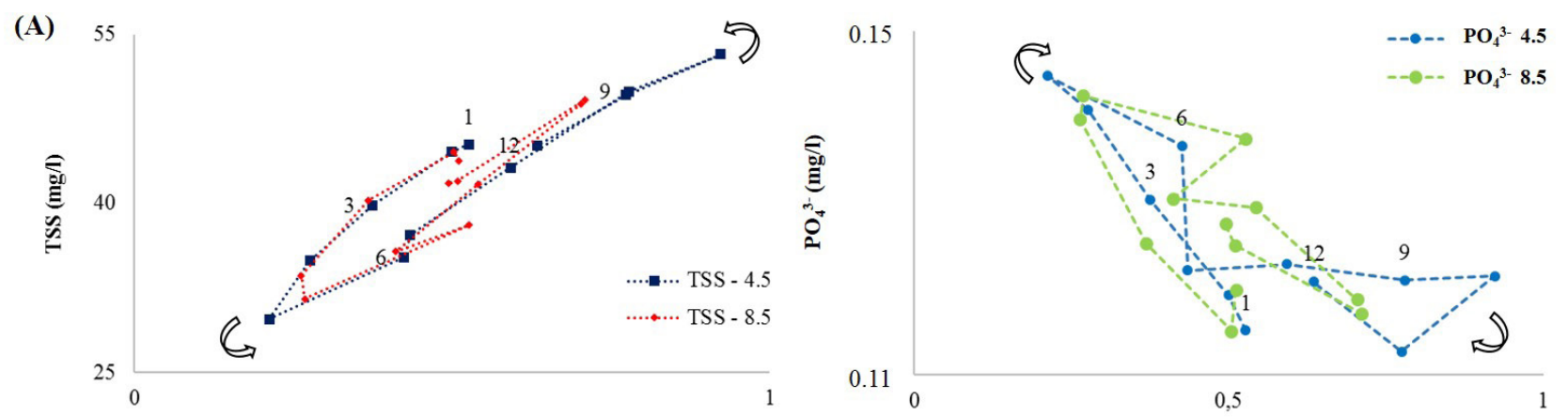

(B)
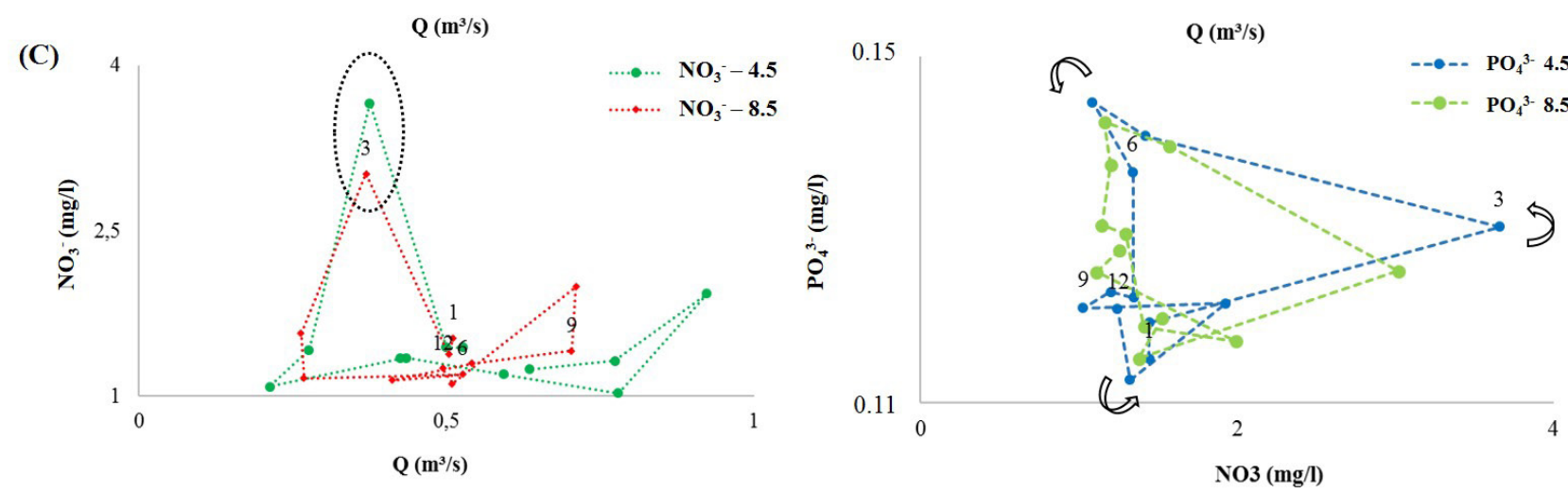

Figure 8. Hysteresis of (A) $\mathrm{Q} \times \mathrm{TSS},(\mathrm{B}) \mathrm{Q} \times \mathrm{PO}_{4}^{3-}$, (C) $\mathrm{Q} \times \mathrm{NO}_{3}^{-}$and (D) $\mathrm{NO}_{3}^{-} \times \mathrm{PO}_{4}^{3-}$ estimating both scenarios for 2015 to 2099 , Concordia Catchment, Southern Brazil.

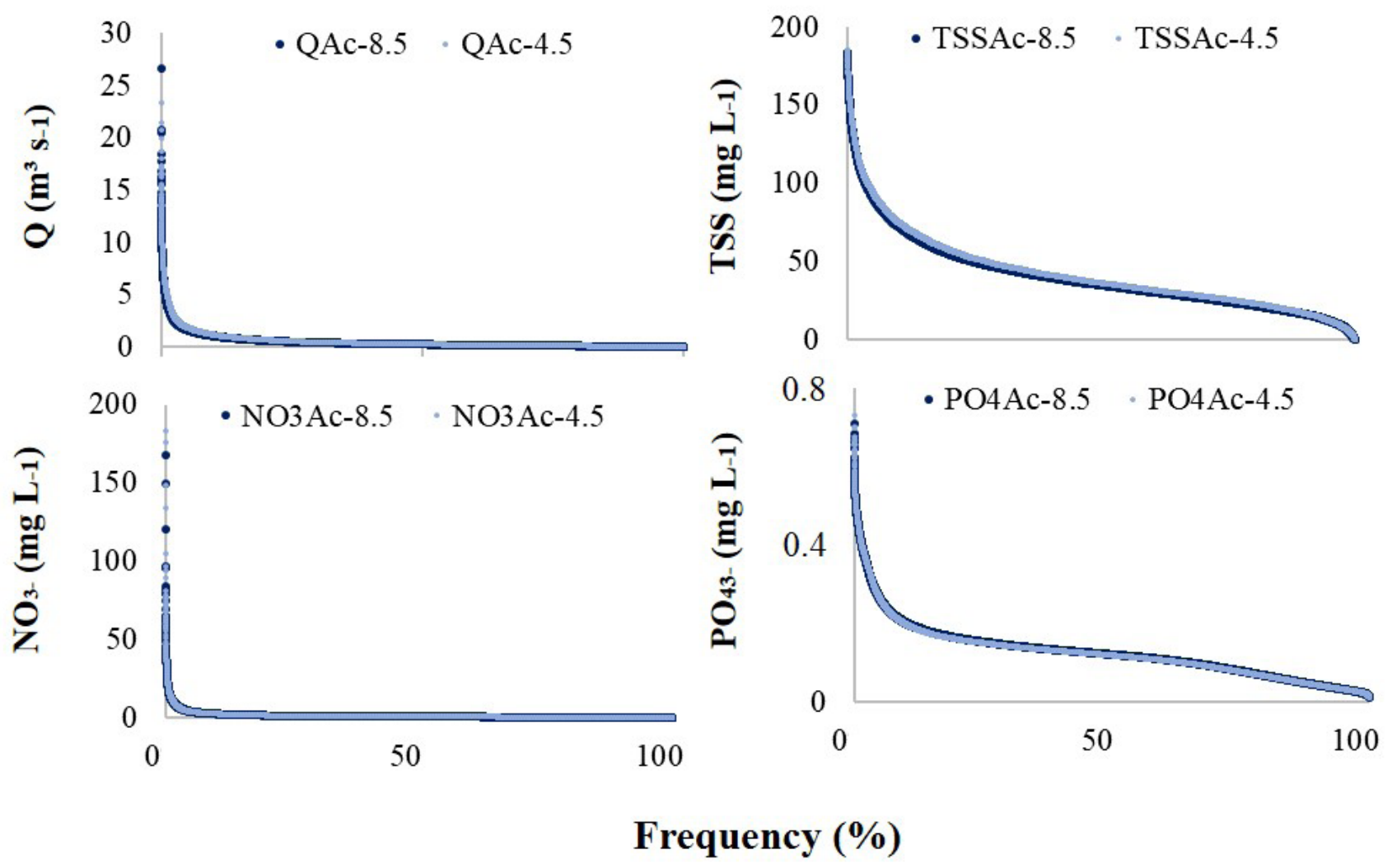

Figure 9. Frequency curves for the 4.5 and 8.5 scenarios (2015 to 2099), Concordia Catchment, Southern Brazil. 


\begin{tabular}{|c|c|c|c|c|c|c|}
\hline & 4.5 scenario & & & & 8.5 scenario & \\
\hline 2 & & $\begin{array}{l}=2015-2024 \\
=2025-2034 \\
=2035-2044 \\
=2045-2054 \\
=2055-2064 \\
=2065-2074 \\
=2075-2004 \\
=20855-2094\end{array}$ & $\mathrm{Q}\left(\mathrm{m}^{3} / \mathrm{s}\right)$ & $\begin{array}{l}2 \\
\\
0\end{array}$ & D & 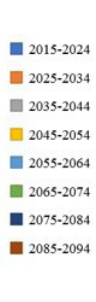 \\
\hline $\begin{array}{r}100 \\
\\
0\end{array}$ & & 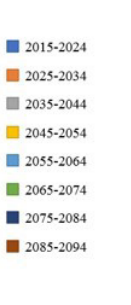 & TSS (mg L L) & 100 & & 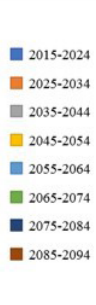 \\
\hline 3 & & 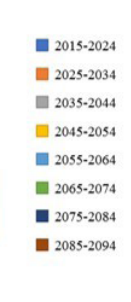 & $\mathrm{NO}_{3}^{-}\left(\mathrm{mg} \mathrm{L}^{-1}\right)$ & 3 & & 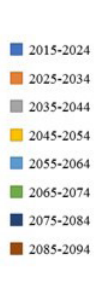 \\
\hline 0.4 & & $\begin{array}{l}=2015-2024 \\
=2025-2034 \\
=2035-2044 \\
=2045-2054 \\
=2055-2064 \\
=20055-2074 \\
=2075-2084 \\
=2085-2094\end{array}$ & $\mathrm{PO}_{4}{ }^{3-}\left(\mathrm{mg} \mathrm{L}^{-1}\right)$ & 0.4 & & 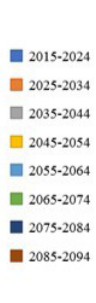 \\
\hline
\end{tabular}

Figure 10. Eight decades: 2015-2024, 2025-2034, 2035-2044, 2045-2054, 2055-2064, 2065-2074, 2065-2074 and $2075-2084$ for the 4.5 and 8.5 scenarios, Concordia Catchment, Southern Brazil.

in the simulated averages of Q, TSS and nutrients. This result was influenced by the agricultural practices used in the calibration step of the SWAT model. In other words, for the simulated scenarios, local agricultural practices demonstrated sustainability in the Concordia Catchment. Family and small/medium-sized farming did not present marked influences in the simulated parameters. Both atmospheric circulation scenarios had little influence on water quantity and quality in the studied catchment, since no changes in land use and application of fertilisers occurred. Changes in hydrological processes and the transport of sediments and nutrients can only be felt in a long time series, with auxiliaries of sampled data. For this type of study, the frequency of monitoring can be moderate (monthly or quarterly), but it should be long and account for all seasons. According to Rodda (1976), patterns and trends in water quality can only be identified with data series of at least twenty (20) hydrological years - such as the case of $\mathrm{NO}_{3}^{-}$in the United Kingdom, with over 30 years of monitoring (BURT; WORRALL, 2009; HOWDEN; BURT, 2008). Only with a long time series can measured data be used for catchment management plans and to support decisions to anticipate the impacts of climate change (LETA et al., 2017).

\section{CONCLUSIONS}

This study evaluated the response of two climatic scenarios (RCP 4.5 and 8.5), generated by the regional Eta Model, on the water quantity (flow - Q) and quality (TSS, $\mathrm{NO}_{3}^{-}$and $\mathrm{PO}_{4}{ }^{3}$ ), using data from the monitoring programme of the Concordia Catchment, inserted in the Atlantic Forest Biome. No effect of the RCP scenarios (4.5 and 8.5 ) in water quantity or quality was identified. The stability in simulated flows, suspended sediment and nutrients, is explained by the influence of conservationist agricultural practices adopted by local farmers. The SWAT model presented a satisfactory response to the average flow; however, it overestimated the maximums, indicating a limitation of the model for properly simulating storm events. For quality simulation, the model also presented limitations, suggesting that further studies will be necessary to better understand these complex processes. 
The natural vegetation presents high attenuation over human activities, which are not intensive, considering TSS, $\mathrm{NO}_{3}^{-}$and $\mathrm{PO}_{4}^{3-}$, up to the analysed horizon of 2099 .

\section{ACKNOWLEDGEMENTS}

We thank Prof. Jose Antonio Marengo Orsini and the INPE for the generation of regionalised climatic scenarios, the FAPESC (grant 2016TR2525) for financial support and the CNPq (process 440938/2017-1) for the productivity scholarship.

\section{REFERENCES}

ABBASPOUR, K. C.; YANG, J.; MAXIMOV, I.; SIBER, R.; BOGNER, K.; MIELEITNER, J.; ZOBRIST, J.; SRINIVASAN, R. Modelling of hydrology and water quality in the pre-alpine/alpine Thur watershed using SWAT. Journal of Hydrology, v. 333, n. 2-4, p. 413-430, 2007. http://dx.doi.org/10.1016/j.jhydrol.2006.09.014.

ALLEN, R. G.; JENSEN, M. E.; WRIGHT, J. L.; BURMAN, R. D. Operational estimates of reference evapotranspiration. Agronomy Journal, v. 81, n. 4, p. 650-662, 1989. http://dx.doi.org/10.2134/ agronj1989.00021962008100040019x.

ALVARENGA, L. A.; MELLO, C. R.; COLOMBO, A.; CHOU, S. C.; CUARTAS, L. A.; VIOLA, M. R. Impacts of Climate Change on the Hydrology of a Small Brazilian Headwater Catchment Using the Distributed Hydrology-Soil-Vegetation Model. American Journal of Climate Change, v. 7, n. 2, p. 355-366, 2018. http:/ / dx.doi. org/10.4236/ajcc.2018.72021.

ANDRADE, M. A. Simulação bidrológica numa bacia bidrográfica representativa dos latossolos na região Alto Rio Grande. 2011. 102 f. Dissertação (Mestrado) - Universidade Federal de Lavras, Lavras, 2011.

ARNOLD, J. G.; KINIRY, J. R.; SRINIVASAN, R.; WILLIAMS, J. R.; HANEY, E. B.; NEITSCH, S. Soil and Water assessment tool input/output file documentation. Texas: Texas Water Resources Institute, 2012a. 654 p.

ARNOLD, J. G.; MORIASI, D. N.; GASSMAN, P. W.; ABBASPOUR, K. C.; WHITE, M. J.; SRINIVASAN, R.; SANTHI, C.; HARMEL, R. D.; VAN GRIENSVEN, A.; VAN LIEW, M. W.; KANNAN, N.; JHA, M. K. SWAT: model use calibration and validation. Transactions of the ASABE, v. 55, n. 4, p. 1494-1508, 2012b. http:/ / dx.doi.org/10.13031/2013.42256.

BÁRDOSSY, A.; PEGRAM, G. Downscaling precipitation using regional climate models and circulation patterns toward hydrology. Water Resources Research, v. 47, n. 4, p. W04505, 2011. http:/ /dx.doi. org/10.1029/2010WR009689.

BEVEN, K. Rainfall-Runoff Modelling: the primer. West Sussex: John Wiley \& Sons, 2001. 360 p.
BLAINSKI, É.; DORTZBACH, D.; PEREIRA, A. P. E.; FARIAS, M. G. Uso de modelo hidrossedimentológico para a simulação de cenários de uso da terra na microbacia Ribeirão Gustavo, Santa Catarina. Revista de Gestão de Água da América Latina, v. 11, n. 1, p. 21-32, 2014. http://dx.doi.org/10.21168/rega.v11n1.p21-32.

BLAINSKI, E.; PORRAS, E. A. A.; GARBOSSA, L. H. P.; PINHEIRO, A. Simulação de cenários de uso e ocupação das terras na bacia hidrográfica do Rio Camboriú utilizando o modelo SWAT. Revista Brasileira de Recursos Hidricos, v. 22, n. e33, 2017.

BRASIL. Plano nacional de adaptação à mudança do clima. Brasília: Ministério do Meio Ambiente, 2016. 329 p.

BRAUMAN, K. A.; DAILY, G. C.; DUARTE, T. K.; MOONEY, H. A. The nature and value of ecosystem services: an overview highlighting hydrologic services. Annual Review of Environment and Resources, v. 32, n. 1, p. 67-98, 2007. http://dx.doi.org/10.1146/ annurev.energy.32.031306.102758.

BRESSIANI, D. A.; GASSMAN, P. W.; FERNANDES, J. G.; GARBOSSA, L.; SRINIVASAN, R.; BONUMA, N. B.; MENDIONDO, E. M. A review of Soil and Water Assessment Tool (SWAT) applications in Brazil: challenges and prospects. International Journal of Agricultural and Biological Engineering, v. 8, n. 3, p. 1-27, 2015.

BRIGHENTI, T. M.; BONUMÁ, N. B.; CHAFFE, P. L. B. Calibração hierárquica do modelo Swat em uma bacia hidrográfica Catarinense. Revista Brasileira de Recursos Hídricos, v. 21, n. 1, p. 53-64, 2016. http://dx.doi.org/10.21168/rbrh.v21n1.p53-64.

BURT, T. P.; WORRALL, F. Stream nitrate levels in a small catchment in south west England over a period of 35 years (1970-2005). Hydrological Processes, v. 23, n. 14, p. 2056-2068, 2009. http://dx.doi.org/10.1002/hyp.7314.

COSTA, C. E. A. S.; BLANCO, C. J. C.; OLIVEIRA-JÚNIOR, J. F. IDF curves for future climate scenarios in a locality of the Tapajós Basin, Amazon, Brazil. Journal of Water and Climate Change, v. 202, p. jwc2019202, 2019.

DIBIKE, Y. B.; COULIBALY, P. Hydrologic impact of climate change in the Saguenay watershed: comparison of downscaling methods and hydrologic models. Journal of Hydrology, v. 307, n. 1-4, p. 145-163, 2005. http://dx.doi.org/10.1016/j.jhydrol.2004.10.012.

EMPRESA BRASILEIRA DE PESQUISA AGROPECUÁRIA EMBRAPA. Mapa de tipo de solos - Escala original de mapeamento: 1:250.000. Sistema de projeção e sistema de referência: WGS 1984 UTM Zone 22S. EMBRAPA, 2004. Disponível em: <http:// mapoteca.cnps.embrapa.br/>. Acesso em: 30 nov. 2018.

FUKUNAGA, D. C.; CECÍLIO, R. A.; ZANETTTI, S. S.; OLIVEIRA, L. T.; CAIADO, M. A. C. Application of the SWAT hydrologic model to a tropical watershed at Brazil. Catena, v. 125, p. 206-213, 2015. http://dx.doi.org/10.1016/j.catena.2014.10.032. 
GASSMAN, P. W.; REYES, M. R.; GREEN, C. H.; ARNOLD, J. G. The soil and water assessment tool: historical development, applications, and future research directions. Transactions of the $A S A B E$, v. 50, n. 4, p. 1211-1250, 2007. http://dx.doi. org/10.13031/2013.23637.

GOSLING, S. N.; TAYLOR, R. G.; ARNELL, N. W.; TODD, M. C. A comparative analysis of projected impacts of climate change on river runoff from global and catchment scale hydrological models. Hydrology and Earth System Sciences, v. 15, n. 1, p. 279-294, 2011. http://dx.doi.org/10.5194/hess-15-279-2011.

GUPTA, H. V.; SOROOSHIAN, S.; YAPO, P. O. Status of automatic calibration for hydrologic models: comparison with multilevel expert calibration. Journal of Hydrologic Engineering, v. 4, n. 2, p. 135-143, 1999. http://dx.doi.org/10.1061/(ASCE)10840699(1999)4:2(135).

HOWDEN, N. J. K.; BURT, T. P. Temporal and spatial analysis of nitrate concentrations from the Frome and Piddle catchments in Dorset (UK) for water years 1978 to 2007: evidence for nitrate breakthrough? The Science of the Total Environment, v. 407, n. 1, p. 507-526, 2008. http://dx.doi.org/10.1016/j.scitotenv.2008.08.042. PMid:18947858.

INTERGOVERNMENTAL PANEL ON CLIMATE CHANGE - IPCC. Climate change 2013: the physical science basis. In: STOCKER, T. F.; QIN, D.; PLATTNER, G.-K.; TIGNOR, M.; ALLEN, S. K.; BOSCHUNG, J.; NAUELS, A.; XIA, Y.; BEX, V.; MIDGLEY, P. M. (Eds.). Contribution of Working Group I to the Fifth Assessment Report of the IPCC. Cambridge: Cambridge University Press. 1535 f. 2013.

KRYSANOVA, V.; WHITE, M. Advances in water resources assessment with SWAT-an overview. Hydrological Sciences Journal, v. 60 , n. 5, p. 771-783, 2015. http://dx.doi.org/10.1080/026266 67.2015 .1029482 .

LELIS, T. A.; CALIJURI, M. L.; SANTIAGO, A. F.; LIMA, D. C.; ROCHA, E. O. Análise de sensibilidade e calibração do modelo SWAT aplicado em bacia hidrográfica da região sudeste do Brasil. Revista Brasileira de Ciência do Solo, v. 36, n. 2, p. 623-634, 2012. http://dx.doi.org/10.1590/S0100-06832012000200031.

LENDERINK, G.; VAN ULDEN, A.; VAN DEN HURK, B.; KELLER, F. A study on combining global and regional climate model results for generating climate scenarios of temperature and precipitation for the Netherlands. Climate Dynamics, v. 29, n. 2-3, p. 157-176, 2007. http://dx.doi.org/10.1007/s00382-007-0227-z.

LETA, O. T.; EL-KADI, A. I.; DULAI, H. Implications of climate change on water budgets and reservoir water harvesting of Nuuanu Area Watersheds, Oahu, Hawaii. Journal of Water Resources Planning and Management, v. 143, n. 11, p. 05017013, 2017. http://dx.doi. org/10.1061/(ASCE)WR.1943-5452.0000839.

MACHADO, R. E.; VETORAZZI, C. A.; XAVIER, A. C. Simulação de cenários alternativos de uso da terra em uma microbacia utilizando técnicas de modelagem e geoprocessamento. Revista Brasileira de Ciência do Solo, v. 27, n. 4, p. 727-733, 2003. http:// dx.doi.org/10.1590/S0100-06832003000400017.

MEAURIO, M.; ZABALETA, A.; BOITHIAS, L.; EPELDE, A. M.; SAUVAGE, S.; SÁNCHEZ-PÉREZ, J. M.; SRINIVASAN, R.; ANTIGUEDAD, I. Assessing the hydrological response from an ensemble of CMIP5 climate projections in the transition zone of the Atlantic region (Bay of Biscay). Journal of Hydrology, v. 548, p. 46-62, 2017. http://dx.doi.org/10.1016/j.jhydrol.2017.02.029.

MEINSHAUSEN, M.; SMITH, S. J.; CALVIN, K.; DANIEL, J. S.; KAINUMA, M.; LAMARQUE, J.; MATSUMOTO, K.; MONTZKA, S.; RAPER, S.; RIAHI, K.; THOMSON, A.; VELDERS, G. J. M.; VAN VUUREN, D. P. P. The RCP greenhouse gas concentrations and their extensions from 1765 to 2300. Climatic Change, v. 109, n. 1-2, p. 213-241, 2011. http://dx.doi.org/10.1007/s10584-011-0156-z.

MORIASI, D. N.; ARNOLD, J. G.; VAN LIEW, M. W.; BINGNER, R. L.; HARMEL, R. D.; VEITH, T. L. Model evaluation guidelines for systematic quantification of accuracy in watershed simulations. Transactions of the ASABE, v. 50, n. 3, p. 885-900, 2007. http:// dx.doi.org/10.13031/2013.23153.

NASH, J. E.; SUTCLIFFE, J. V. River flow forecasting through conceptual models: part I. a discussion of principles. Journal of Hydrology, v. 10, n. 3, p. 282-290, 1970. http://dx.doi.org/10.1016/00221694(70)90255-6.

NEITSCH, S. L.; ARNOLD, J. G.; KINIRY, J. R.; WILLIAMS, J. R. Soil and water assessment tool: theoretical documentation - Version 2009. Texas: Texas AgriLife Research, 2011. 618 p.

OUYANG, F.; ZHU, Y. H.; FU, G. B.; LU, H. S.; ZHANG, A. J.; YU, Z. B.; CHEN, X. Impacts of climate change under CMIP5 RCP scenarios on streamflow in the Huangnizhuang Catchment. Stochastic Environmental Research and Risk Assessment, v. 29, n. 7, p. 1781-1795, 2015. http://dx.doi.org/10.1007/s00477-014-1018-9.

PAPARRIZOS, S.; MARIS, F.; MATZARAKIS, A. Integrated analysis of present and future responses of precipitation over selected Greek areas with different climate conditions. Atmospheric Research, v. 169, p. 199-208, 2016. http://dx.doi.org/10.1016/j. atmosres.2015.10.004.

PIAZZA, G. A.; DUPAS, R.; GASCUEL-ODOUX, C.; GRIMALDI, C.; PINHEIRO, A.; KAUFMANN, V. Influence of hydroclimatic variations on solute concentration dynamics in nested subtropical catchments with heterogeneous landscapes. The Science of the Total Environment, v. 635, p. 1091-1101, 2018. http://dx.doi.org/10.1016/j. scitotenv.2018.03.394. PMid:29710564.

PIAZZA, G. A.; TORRES, E.; MOSER, P.; GOTARDO, R.; KAUFMANN, V.; PINHEIRO, A. Análise Espacial e temporal dos dados de precipitação das estações de entorno da Bacia do Ribeirão Concórdia, Lontras (SC), visando sua inserção no contexto de mudanças climáticas. Revista Brasileira de Meteorologia, 
v. 31, n. 4, p. 580-592, 2016. http://dx.doi.org/10.1590/0102$7786312314 \mathrm{~b} 20150087$.

RODDA, J. C. Basin studies. In: RODDA, J. C. (Ed.). Facets of bydrology. Hoboken: John Wiley \& Sons, 1976. p. 257-297.

SANTHI, C.; ARNOLD, J. G.; WILLIAMS, J. R.; DUGAS, W. A.; SRINIVASAN, R.; HAUCK, L. M. Validation of the SWAT model on a large river basin with point and nonpoint sources. Journal of the American Water Resources Association, v. 37, n. 5, p. 1169-1188, 2001. http://dx.doi.org/10.1111/j.1752-1688.2001.tb03630.x.

SELLAMI, H.; BENABDALLAH, S.;JEUNESSE, I.; VANCLOOSTER, M. Quantifying hydrological responses of small Mediterranean catchments under climate change projections. The Science of the Total Environment, v. 543, n. Pt B, p. 924-936, 2016. http:/ /dx.doi. org/10.1016/j.scitotenv.2015.07.006. PMid:26170115.

SILVA, V. A.; MOREAU, M. S.; MOREAU, A. M. S. S.; REGO, N. A. C. Uso da terra e perda de solo na Bacia Hidrográfica do Rio Colônia, Bahia. Revista Brasileira de Engenharia Agricola e Ambiental, v. 15, n. 3, p. 310-315, 2011. http://dx.doi.org/10.1590/S141543662011000300013.

STRAUCH, M.; LORZ, C.; MAKESCHIN, F.; LIMA, J. E. W.; KOIDE, S. Modelling land use effects on water resources. Distrito Federal: Integrated Water Resources Management, 2012. Final Workshop Project IWAS ÁGUA.

TAFFARELLO, D.; SRINIVASAN, R.; MOHOR, G. S.; GUIMARÃES, J. L. B.; CALIJURI, M. C.; MENDIONDO, E. M. Modeling freshwater quality scenarios with ecosystem-based adaptation in the headwaters of the Cantareira system, Brazil. Hydrology and Earth System Sciences, v. 22, n. 9, p. 4699-4723, 2018. http://dx.doi.org/10.5194/hess-22-4699-2018.

TAN, M. L.; FICKLIN, D. L.; IBRAHIM, A. L.; YUSOP, Z. Impacts and uncertainties of climate change on streamflow of the Johor River Basin, Malaysia using a CMIP5 General Circulation Model ensemble. Journal of Water and Climate Change, v. 5, n. 4, p. 676-695, 2014. http://dx.doi.org/10.2166/wcc.2014.020.

TAN, M. L.; TAN, K. C.; CHUA, V. P.; CHAN, N. W. Evaluation of TRMM product for monitoring drought in the Kelantan River Basin, Malaysia. Water, v. 9, n. 1, p. 57, 2017. http://dx.doi. org/10.3390/w9010057.

TAYLOR, K. E.; STOUFFER, R. J.; MEEHL, G. A. An overview of CMIP5 and the experiment design. Bulletin of the American Meteorological Society, v. 93, n. 4, p. 485-498, 2012. http://dx.doi. org/10.1175/BAMS-D-11-00094.1.

TEUTSCHBEIN, C.; SEIBERT, J. Bias correction of regional climate model simulations for hydrological climate-change impact studies: review and evaluation of different methods. Journal of Hydrology, v. 456-457, p. 12-29, 2012. http://dx.doi.org/10.1016/j. jhydrol.2012.05.052.

THEMESSL, M. J.; GOBIET, A.; LEUPRECHT, A., Empiricalstatistical downscaling and error correction of daily precipitation from regional climate models. The International Journal of Climatology, v. 31, n. 10, p. 1530-1544, 2011. http://dx.doi.org/10.1002/joc.2168.

URRUTIA, R.; VUILLE, M. Climate change projections for the tropical Andes using a regional climate model: temperature and precipitation simulations for the end of the 21 st century. Journal of Geophysical Research Atmospheres, v. 114, n. D2, p. 1-15, 2009. http://dx.doi.org/10.1029/2008JD011021.

VAN VUUREN, D. P.; EDMONDS, J.; KAINUMA, M.; RIAHI, K.; THOMSON, A.; HIBBARD, K.; HURTT, G. C.; KRAM, T.; KREY, V.; LAMARQUE, J.-F.; MASUI, T.; MEINSHAUSEN, M.; NAKICENOVIC, N.; SMITH, S. J.; ROSE, S. K. The representative concentration pathways: an overview. Climatic Change, v. 109, n. 1-2, p. 5-31, 2011. http://dx.doi.org/10.1007/s10584-011-0148-z.

VIOLA, M. R.; MELLO, C. R.; CHOU, S. C.; YANAGI, S. N.; GOMES, J. L. Assessing climate change impacts on Upper Grande River Basin hydrology, Southeast Brazil. International Journal of Climatology, v. 35, n. 6, p. 1054-1068, 2015. http://dx.doi. org/10.1002/joc.4038.

VÖRÖSMARTY, C. J.; MCINTYRE, P. B.; GESSNER, M. O.; DUDGEON, D.; PRUSEVICH, A.; GREEN, P.; GLIDDEN, S.; BUNN, S. E.; SULLIVAN, C. A.; LIERMANN, C. R.; DAVIES, P. M. Global threats to human water security and river biodiversity. Nature, v. 467, n. 7315, p. 555-561, 2010. http://dx.doi.org/10.1038/ nature09440. PMid:20882010.

WILLIAMS, J. R. Sediment routing for agricultural watersheds. Water Resources Bulletin, v. 11, n. 5, p. 965-974, 1975. http://dx.doi. org/10.1111/j.1752-1688.1975.tb01817.x.

YESUF, H. M.; MELESSE, A. M.; ZELEKE, G.; ALAMIREW, T. Streamflow prediction uncertainty analysis and verification of SWAT model in a tropical watershed. Environmental Earth Sciences, v. 75, n. 9, p. 1-16, 2016. http://dx.doi.org/10.1007/ s12665-016-5636-z.

ZHANG, Y.; YOU, Q.; CHEN, C.; GE, J. Impacts of climate change on streamflows under RCP scenarios: a case study in Xin River Basin, China. Atmospheric Research, v. 178-179, p. 521-534, 2016. http://dx.doi.org/10.1016/j.atmosres.2016.04.018.

\section{Author's contributions}

Adilson Pinheiro: Paper conception, data analysis, results, discussion and journal guidelines.

Vander Kaufmann: SWAT run, calibration, data analysis and equipment installation.

Gustavo Antonio Piazza: Paper conception, research, literature review, discussion and paper writing.

Claudia Guimarães Camargo Campos: Processing of climate scenarios. 